Mikaël Philip J. Bauer*

\title{
The Chronicle of Jōe - A Translation of the Second Part of the History of the Fujiwara House
}

https://doi.org/10.1515/asia-2017-0084

Keywords: Fujiwara, Jōe den, Tōshi Kaden, Fujiwara no Nakamaro, Nakatomi no Kamatari

\section{Introduction}

The Chronicle of Jōe, Jōe den 貞慧伝, is the second part of the Tōshi Kaden 藤氏 家伝 or History of the Fujiwara House composed around the middle of the 8th century. ${ }^{1}$ While commonly attributed to Enkei 延慶 (?-?), a monk close to Fujiwara no Nakamaro 藤原仲麻呂 (706-764), this biography's authorship remains far from clear. The first part of the History recounts the life of the Fujiwara patriarch, Kamatari 藤原鎌足 (614-669), and this second part deals with the short life of his son and monk Jōe 貞慧 (643-665). ${ }^{2}$ Originally a biography of Kamatari's other son, the illustrious Fujiwara no Fuhito 藤原不比等 (659-720) was included as well, but this part is unfortunately no longer extant.

Despite the mysterious circumstances regarding his early death, not much is known about Kamatari's eldest son. He does appear in a few other sources such as the Tōnomine ryakki 多武峰略記 and the Genkō Shakushō 元亨釈書, but these are much later sources. In these later stories, Jōe's involvement with Kamatari's funeral (not mentioned in The Chronicle of Kamatari) or his being the son of the sovereign (Kōtoku 孝徳), and not Kamatari, are elaborated upon. ${ }^{3}$ Historically, we only know that Jōe, Kamatari's son or not, was sent to T'ang China at a very young age, that he studied there for several years, and died suddenly soon after

1 For the translation of the first part of the History of the Fujiwara House, the Chronicle of Kamatari, see Bauer, 2017.

2 Also written as 貞恵.

3 For a translation of this passage from the Genkō Shakushō, see Bingenheimer 2001: 116-117. Bingenheimer also mentions that the The Chronicle of Jōe might be more historically reliable than these later accounts; Bingenheimer 2001: 119.

*Corresponding author: Mikaël Philip J. Bauer, McGill University, Birks Building 004, 3520 rue University, Montreal, QC H3A 2A7, Canada. E-mail: mikael.bauer@mcgill.ca 
his return to the Japanese court, in 665. Both the Nihon Shoki 日本書記 and The Chronicle of Jōe suggest that he was poisoned, possibly by men from Paekche, but there are no sources to accept or reject this claim.

The connection between The Chronicle of Kamatari and The Chronicle of Jōe has been researched by several Japanese scholars. According to Endō Keita 遠藤 慶太, the first part of The Chronicle of Jōe is a clear continuation of the final part of The Chronicle of Kamatari and a similar statement is made by Okimori Takuya. ${ }^{4}$ It remains unclear, however, whether the Jōe den was written independently or as as part of The Chronicle of Kamatari. Another line of Japanese research concerns the relation between The Chronicle of Jōe, the History of the Fujiwara House as a whole, and the religious and institutional policies of Fujiwara no Nakamaro. ${ }^{5}$ The translation below was made from the annotated edition by Okimori Takuya in his Tōshi kaden, Kamatari, Jōe, Muchimaro den, chūshaku to kenkyū.

\subsection{Translation}

Jōe's character was wise and he loved to study. ${ }^{6}$ The Great Minister considered him different but despite being as hard as steel, if he could not forge him, how could he benefit from Gan Jiang? ${ }^{7}$ Despite being as strong as an arrow, if he could not attach a bundle of feathers, how could he attain the beauty of Kuai Ji? ${ }^{8}$ He alienated himself from his parents' benevolence and sought the peculiarity of the high seat. ${ }^{9}$

In the fifth year of Hakuhō [677 CE], he arrived in Chang' an, accompanying a mission to the T'ang. ${ }^{10}$ He resided at the temple of Huiri at Huaidefang where he studied under master of the Dharma Shentai. ${ }^{11}$ This was in the fourth year of

4 Fujii 2011: 217.

5 See for example Kuranaka 2000 and Endō 2011.

6 The name Jōe is written in several ways: “貞慧” or “貞恵”. the TK edited text uses “貞慧”.

7 "The Great Minister" (大臣) refers his father, Nakatomi/Fujiwara no Kamatari; "benefit from Gan Jiang” [干将之利] refers to one of a pair of mythical swords, the other one being Mo ye (莫 耶).

8 Kuai Ji (会稽) refers to a mythical arrow made from bamboo cultivated at mount Kuai Ji (会稽 山), TK, 263. A similar metaphor can be found in the Huainanzi (准南子); TK, 263-264.

9 “Peculiarity of the high seat” [席上之珍] is taken by Okimori as referring to Confucianism, as the expression is also found in the $\mathrm{Li} \mathrm{Ji}, \mathrm{TK}, 263$. However, the following sentence starts with yue ni (故), "therefore", and continues to explain he went on to study Buddhism. For this reason, I suspect the "high seat" here refers to a Buddhist, and not a Confucian talent.

10 Full date: 白鳳五年歳次甲寅. TK, 264.

11 Huiri (慧日; ?-748), DDB entry. A well-known T’ang monk and disciple of Yijing. Shentai (神 泰) was a disciple of Xuanzang and was known for his refutation of Daoist ideas, DDB Shentai 
the Tang's Yong Hui era and at the time he was eleven years old. From when he immersed himself in the way of the Buddha he did not waste day or night. For more than ten years he studied under his teacher. He mastered the Buddhist canon and also understood the Daoist and Confucian texts. ${ }^{12}$ He was able to visualize poetry and observe the rules of composition.

From the ninth month, autumn, of the sixteenth year of Hakuhō [688 CE], he returned to the capital from Kudara. ${ }^{13}$ He recited one line from a poem about his days in Kudara. It read:

Separated from the court by a thousand li

I gaze at autumn at the border vestige $e^{14}$

Closely reading these lines meticulously, the talented of the day could not yet grasp their depth. ${ }^{15}$ In secret, Kudara's gentry was jealous of his abilities and they poisoned him. On the twenty-third day of the twelfth month of that year he passed away in his mansion in Ōhara. ${ }^{16} \mathrm{He}$ had twenty-three springs and autumns. The monastic and the lay shed tears, and the heart of the court was in pain. ${ }^{17}$

The monk Dōgen from Kōryō composed an epithet ${ }^{18}$ :

"When you, Great Minister, divined our destiny, you based yourself on the former Classics; when you clarified the old and the new, you used the country's eternal laws. ${ }^{19}$ Those who untangle the thread at the purple quarters, consider it

entry. The temple in Chang' an where he worked with Xuanzang was called Hongfusi (Jap: Kōfukuji, 弘福寺). TK, 264-265.

12 Naikyō (内経) or “Buddhist canon” and geten (外典) or “Daoist and Confucian texts”.

13 Full date: 白鳳十六年歳次乙丑秋九月, TK, 267.

14 Translated by Bingenheimer as "Ten thousand miles away is the emperor's city, all around the city walls, autumn everywhere.” Bingenheimer 2001: 116. The poem reads: 帝郷千理隔辺 城四望秋; TK, 267-277.

15 This could be taken as certain members of the court not being able to continue the poem in a poetry exchange.

16 This is in the year 665, TK, 269. A radically different, and much later, date (714) is provided in the Genkō Shakushō (元亨釈書). This text also situates his return from China in 678. However, since no documentation by or about Jōe exists for the years following 665, I consider the date in the Chronicle of Jōe reliable. See Bingenheimer 2001: 116-118 for a translation of the passage from the Genkō Shakushō.

17 The "Court" refers here to the "state" or chōya (朝野).

18 Dōgen (道賢; also written as 道顕) appears in the Chronicle of Kamatari; Bauer 2017: 489. Kōryō (高麗) or Goryeo.

19 "Great Minister" is not expressed in the text, instead "you" (夫) is added. I interpret this first part as linking Jōe with the virtue of his father. This would make sense keeping in mind the larger context of the entire History of the Fujiwara House, which is to celebrate the patriarch, 
fundamental to encourage intelligence; those who bring brilliance to the sovereign's household, consider it fundamental to raise virtue. ${ }^{20}$ Therefore, the Duke of Zhou himself used the three rods on Bo Qin, and Kong Zi used the two teachings for Kong $\mathrm{Li}^{21}{ }^{21} \mathrm{Accordingly}$, you provided order to the state from afar while clearly it wasn't your private duty to do so. If one contemplates this matter, the courageous in general confront the world by establishing their reputation and glorifying their position. They exploit their abilities and discard their inabilities; there is nothing they do not know. Even more, their generosity and stringency complement each other, and thus splendour and plainness transform one another. These are the achievements of holy ones. ${ }^{22}$ Probably, only you were such a man. You practiced supreme virtue, and you transcended the highest mountains. If one would have just one of your qualities, one would already excel in virtue.

Thereupon, the Great Minister appointed you a Master of the Dharma and dispatched you to the T'ang to study. ${ }^{23}$ You both were alike in study and there was nothing you did not learn. ${ }^{24}$ You had the Qi $\mathrm{Lu}$ in your mind and the $\mathrm{Wu}$ Che in your chest. ${ }^{25}$ You had insight into misfortune and fortune, and you profoundly polished your actions. ${ }^{26}$ Gui Gu wept once again and was afraid you would separate yourself from the gentry. ${ }^{27}$ You studied diligently. The potter

Kamatari, and demonstrate the unbreakable link between the sovereign main, moral servants (the Fujiwara) and the imperial line. Given Jōe's young age when he was sent to China (he was barely eleven), he could also hardly have conducted policy in the sovereign's quarters mentioned in this first part. In addition, Kamatari is here compared with Kong Zi, and Jōe to the latter's children.

20 “The purple quarters” or “紫煈” refers to the imperial living quarters; TK, 271. This could mean that it is one of the prime responsibilities of a minister to assemble the talented at court. 21 Bo Qin (伯禽) was the Duke of Zhou’s son Kong Li (孔 • ) was the son of Kong Li (Confucius). A parallel is drawn between these great figures and Kamatari and his son Jōe; TK, 272.

22 “Holy ones” or “聖人”, a Buddhist reference.

23 The text now turns to addressing Jōe. "Great Minister" is not directly expressed in the text, but I agree with Okimori that the subject of the sentence most likely is indeed Kamatari, and the "Master of the Dharma” (法師) his son Jōe.

24 This sentence compares father and son, the Fujiwara Patriarch Kamatari and Jōe, and then moves on to just the son("he"). In the prior paragraph, Kamatari was compared to Kong $\mathrm{Zi}$, while in the second Jōe is compared to Kamatari. This creates the image of moral Fujiwara lineage.

25 Qi Lu (七略); Wu Che (五車), both refer to compendia; TK, 275.

26 "Misfortune and fortune" (否泰) comes from 否塞 and 通泰, these terms appear in the $I$ Ching, TK, 275.

27 Gui Gu (鬼谷); this expression refers to a teacher’s tears when confronted with a student's progress. Here it means that the T'ang court was so impressed that they did not want to see him return to the Japanese court. 
creates pottery and the smith forges gilded objects. ${ }^{28}$ In this manner you, knowledgeable about the arts, possessed unprecedented talent. Because of this, you instantly understood Heaven's orders, accepted the burden and ordered a palanquin. ${ }^{29}$ Moreover, following an imperial order, Guo Wu Zong and Liu De Gao treated you lovingly from morning till evening and respectfully returned you to the Yamato court. You crossed the sea route and arrived here, at the old capital. ${ }^{30}$ His Holiness issued an order, and happily you accepted to go to his home. ${ }^{31}$ After having been there for some time, you rested on a sick bed and the cotton thread's movement had grown dim. ${ }^{32}$ Ah! Why did this happen? This was on the twenty-third day of the twelfth month of Hakuhō sixteen. ${ }^{33}$ After too few spring and autumns, you passed away at the mansion in Ōhara. Ah, how lamentable!"

Following, a death poem read:

\author{
Foundation of our sovereign, \\ governance illumined your house. ${ }^{34}$ \\ So erudite and benevolent, \\ wings protected our policies. \\ of a high repute, \\ promulgating the court's policies. \\ Oh! Mountain. Oh! Sea, \\ A fortress! A wall! \\ Regulating fishing for ritual, \\ just like Zang Xibo. ${ }^{35}$ \\ Fortune through good deeds, \\ left to this wise. ${ }^{36}$ \\ Seeking the Western Tang
}

28 “He studied diligently” is a translation for the expression “韋編一 • ”; “韋編三 • ” appears in the Shiji, TK, 276.

29 Description of his accepting the role as emissary to the T'ang.

30 The "old capital” is probably Asuka (飛鳥).

31 His holiness (聖人) refers to the sovereign, here Tenji.

32 Refers to the expression (纊微) in which a thread was used to measure someone's breathing. In other words, his breathing gradually slows down and he passes away. TK, 279.

33 Complete date: 白鳳十六年歳次乙丑十二月廿三日.

34 The one addressed here is Kamatari, whose qualities were passed on to his son.

35 藏僖伯; this passage refers to the official Zang Xibo who is mentioned in the Zuozhan as stating that living beings such as fish should not be killed unless for ritual use benefitting the state. See Sterckx 2002: 145-146.

36 The "wise" is Jōe. The focus now shifts from Kamatari to his son, but it is significant that Jōe's importance is described based on his father's character and achievements. 


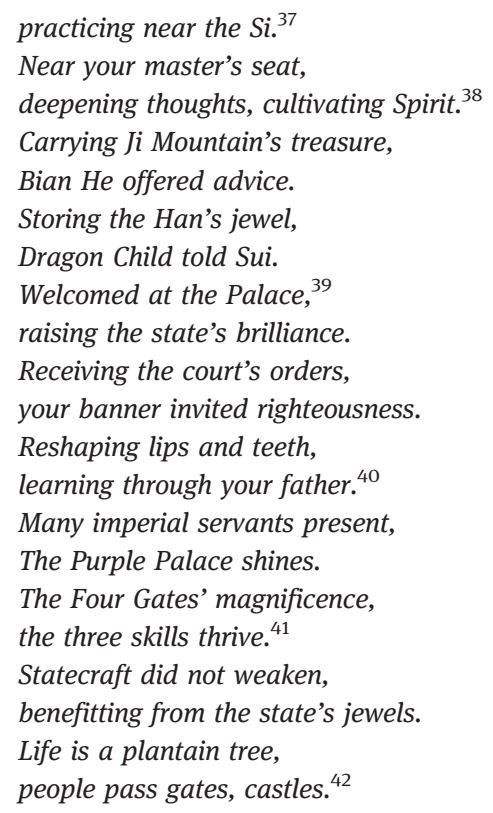

37 This refers to Kong Zi instructing his disciples on the banks of the river Si. Just like in the passages above, the Fujiwara patriarch's morality is compared with Kong Zi's character.

38 This sentence is reminiscent of the following passage of the The Chronicle of Kamatari, describing the close relationship between Kamatari and his sovereign, Tenji: "When they went out they shared a carriage or rode horse side by side. Inside, their cushions touched and their knees were close." The ability to be able to be in the close, physical proximity of the ruler, reveals the importance of the servant. Bauer 2017: 490.

39 The "palace" probably refers to the T'ang court where Jōe represented the Japanese court as an emissary, but also where he was educated. He was only eleven years old upon arrival and no doubt received instruction there.

40 “Lips and teeth” (脣歯) refers the closeness of the T'ang court and Japan; TK, 285. "Your father” refers to Kamatari and once again describes the son while celebrating the Fujiwara patriarch.

41 The "three skills" are literary, military and oratory skills; TK, 286.

42 "Life is a plantain tree (芭蕉)" refers to the impermanence of life. The metaphor of the plantain (banana) tree can be found in both Buddhist scriptures and later Japanese poetry. For example, in the Vimalakīrti Sūtra, this tree is mentioned twice: "This body is like a bubble that cannot continue for long. This body is like a flame born of longing and desire. This body is like the plantain that has no firmness in its trunk. This body is like a phantom, the product of error and confusion." (chapter 2) and "As the wise view the moon in the water, or a face or form seen in a mirror; as shimmers of heat in a torrid season, as the echo that follows a cry, as clouds in the sky, as foam on the water, bubbles on the water, as a thing no firmer that the trunk of the plantain, no longer lasting than a flash of lightning” (chapter 7). See Watson 1997: 35, 83.

See also several Haiku and Noh plays where the image of the plantain tree is used to describe the frugality of the human body and life. For example, in Zeami's Noh play "Izutsu” (井筒) we 
Wisteria are easily cut,

difficult to confine serpents! $!^{43}$

Orchids shrivel in Spring,

pines wither in Summer.

The Phoenix, shot by arrows,

the bullfinch, ending in nets.

Ah! How Lamentable!

When Yan Hui was unfortunate,

Heaven was in mourning. ${ }^{44}$

When Ji zi buried his son,

he expressed his vows. ${ }^{45}$

In writing you live on,

but where are your body and soul?

Seeing what you left, I think of you.

The Palace did not promote you.

Ah! How lamentable!

The cart and jewel reach Wei, the castle's jade has left Chao.

Your talents should be cherished, days returning, evenings fall.

Ah! How lamentable!

\section{Bibliography}

\section{Primary Sources}

TK = Okimori Takuya 沖森卓也, Satō Makoto 佐藤真, Yajima Izumi 矢嶋泉 (ed.) (1999): Tōshi kaden 藤氏家伝 Tōshi kaden, Kamatari, Jōe, Muchimaro den chūshaku to kenkyū 藤氏家 伝、鎌足、貞慧、武智麻呂伝 : 注勫と研究, Tōkyō: Yoshikawa Kōbunkan. NS = Kuroita Katsumi 黒板勝美 (ed.) (1998): Nihon Shoki 日本書. Kokushi Taikei 国史大系 1. Tōkyō: Yoshikawa Kōbunkan.

read: “...the leaves of the plantain tree, rustling in the wind through the pines...” (松風が摇らす 芭蕉の葉のうちに); for an english translation and explanation, see 'Izutsu' on http://www.thenoh.com or Tyler 1992: 120-132.

43 "Wisteria" or sotō ( 鼠藤), equally a metaphor for the shortness of life, TK, 288; reference to the four serpents of earth, water, fire and wind; TK, 288.

44 Yan Hui (顔回) was a disciple of Kong Zi. Jōe, as son of Kamatari, is here compared with Kong Zi's student.

45 Jizi of Yanling buried his son between Ying and Bo. He is mentions as being an example of propriety in the Book of Rites (Liji), Tan Gong II, verse 196. See Chinese Text Project: http:// ctext.org/all-texts?filter $=\mathrm{d} 578$ 


\section{Secondary Sources}

Bauer, Mikaël (2017): “The Chronicle of Kamatari”. Asiatische Studien / Études Asiatiques 71.2: 477-496.

Bingenheimer, Marcus (2001): “A Biographical Dictionary of the Japanese Student-Monks of the Seventh and Eight Centuries". Buddhismus-Studien 4: entire issue.

Shinokawa Ken 篠川賢, Masuo Shin’ichirō 増尾伸一郎 (ed.) (2011): Tōshi Kaden wo yomu 藤氏 家伝を読む. Tōkyō: Yoshikawa Kōbunkan.

Endō, Keita 遠藤慶太(2011): “Nyūtō zō Jōe to Fujiwara no Kamatari” 入唐僧と藤原の鎌足 In: Tōshi Kaden wo yomu 藤氏家伝を読む. Edited by Shinokawa Ken and Masuo Shin’ichirō. Tōkyō: Yoshikawa Kōbunkan.

Fujii Yukiko 藤井紀子 (2011): “Fujiwara Nakamaro to nyūtō zō Jōe” 藤原仲麻呂と入唐僧貞慧. In: Tōshi Kaden wo yomu. Edited by Shinokawa Ken, Masuo Shin’ichirō. Tōkyō: Yoshikawa Kōbunkan.

Kuranaka Shinobu 蔵中しのぶ (2000): “Jōe den wa naze ritsuden sareta ka” 貞慧伝はなぜ立伝 されたか. In: Nihon Bungaku 日本文学 49-11: 80-85.

Sterckx, Roel (2002): The Animal and the Daemon in Early China. Albany: State University of New York Press.

Tyler, Royall (1992): Japanese Nō Dramas. London: Penguin Classics.

Watson, Burton (1997): The Vimalakirti Sutra. New York: Columbia University Press.

\section{Digital Sources}

Chinese Text Project (2006): Tan Gong II. http://ctext.org/all-texts?filter =d578 (28/11/2017). The-Noh.com (2017): Izutsu. http://www.the-noh.com (28/11/2017). 